\title{
EFEKTIFITAS BIAYA PENGGUNAAN SEFTRIAKSON DAN SEFIKSIM PADA PASIEN DEMAM TIFOID RAWAT INAP DI RSU ANUTAPURA PALU PERIODE 2015-2017
}

\author{
(COST EFFECTIVENESS ANALYSIS OF CEFTRIAXONE AND CEFIXIME TO INPATIENTS OF \\ TYPHOID FEVER AT ANUTAPURA PALU GENERAL HOSPAL IN 2015-2017 PERIOD)
}

\author{
NURUL JANNAH ${ }^{1 *}$, IHWAN ${ }^{1}$, M. RINALDHI TANDAH ${ }^{1}$ \\ ${ }^{1}$ Jurusan Farmasi, Fakultas MIPA, Universitas Tadulako, Palu, Indonesia, 90245
}

\begin{abstract}
Abstrak: Penyakit demam tifoid merupakan penyakit infeksi yang disebabkan oleh bakteri Salmonella thypi. Antibiotik merupakan golongan obat yang digunakan untuk menyembuhkan penyakit infeksi salah satunya adalah penyakit demam tifoid. Beberapa antibiotik yang tercatat resisten yaitu kloramfenikol yang dapat menyebabkan terjadinya efek samping seperti depresi sumsum tulang dan anemia aplastik. Di Indonesia Pembiayaan semakin meningkat dari tahun ke tahun. Penggunaan antibiotik dengan biaya yang relatif tinggi belum tentu bisa menjamin efektifitas biaya perawatan pasien. Penelitian ini merupakan penelitian yang bersifat kuantitatif dengan pengambilan data dilakukan secara retrospektif, menggunakan data sekunder berupa rekam medik dan bukti pembayaran pengobatan serta membandingkan direct medical cost (biaya langsung medis) dari penggunaan antibiotik seftriakson dan sefiksim pada pasien demam tifoid yang menjalani rawat inap di rumah sakit umum Anutapura Palu periode 2015-2017. Hasil penelitian menunjukkan antibiotik yang memiliki efektifitas yang tinggi namun memiliki biaya rendah adalah antibiotik sefiksim dengan persen efektifitas (35,71\%) dan nilai ACER Rp60.781,97serta ICER Rp53.676,45.
\end{abstract}

Kata kunci: Analisis Efektifitas Biaya, Antibitok, Demam Tifoid, RSU Anutapura Palu

\begin{abstract}
Typhoid fever is an infectious disease caused by Salmonella thypi bacteria. Antibiotics is a class of drugs used to cure infectious diseases one of them is typhoid fever disease. Some of the antibiotics listed are resistant, chloramphenicol, which can cause side effects such as bone marrow depression and aplastic anemia. In Indonesia Financing is increasing from year to year. The use of antibiotics with relatively high cost may not guarantee the cost effectiveness of patient care. This research is a quantitative research with retrospective data retrieval, using secondary data in the form of medical records and proof of payment of treatment and comparing direct medical costs of the use of antibiotics ceftriaxone and cefixim in patients with typhoid fever who underwent inpatient at home general pain of Anutapura Palu period 2015-2017. The results showed that antibiotics that have high effectiveness but have low cost are cefixim antibiotics with percent effectiveness (35,71\%) and ACER Rp60.781,97and ICER Rp53.676,45.
\end{abstract}

Keywords: Antibiotic, Anutapura Palu General Hospital, Cost Effectiveness Analysis, Typhoid Fever

\section{PENDAHULUAN}

Penyakit demam tifoid merupakan penyakit infeksi yang disebabkan oleh bakteri Salmonella thypi, dengan pengobatan yang memerlukan antibiotik. Obat yang digunakan sebagai pengobatan lini pertama untuk demam tifoid yaitu kloramfenikol, ampisilin atau amoksisilin dan kotrimoksazol. Antibiotik alternatif lain untuk pengobatan demam tifoid yaitu golongan sefalosporin generasi ketiga (seftriakson dan sefotaksim secara intravena, sefiksim secara oral), dan golongan fluoro-kuinolon (Haluang et al., 2015).

Insiden demam tifoid tinggi (>100 kasus per 100.000 populasi per tahun) dicatat di Asia Tengah dan Selatan, Asia Tenggara, dan kemungkinan Afrika Selatan; yang tergolong sedang (10-100 kasus per 100.000 populasi per tahun) di Asia lainnya, Afrika, Amerika Latin, dan Oceania (kecuali Australia dan Selandia Baru); serta yang termasuk rendah (Nelwan, 2012). Beberapa antibiotik yang tercatat resisten yaitu kloramfenikol, ampisilin, dan sulfametoksazol, sehingga perlu untuk mengevaluasi obat baru untuk pengobatan demam tifoid. Terjadinya kekambuhan dan efek samping dari kloramfenikol seperti depresi sumsum tulang dan anemia aplastik juga menjadi alasan untuk mencari alternatif terapi lain (Susono et al., 2014).

Di Indonesia pembiayaan kesehatan semakin meningkat dari tahun ke tahun. Kenaikan biaya kesehatan terjadi akibat penerapan teknologi canggih (Andayani, 2013). Misalnya pada penyakit

\footnotetext{
* email korespondensi: nuruljannah508@yahoo.com
} 
demam tifoid, dilakukan tes uji widal, tes tubex, PCR (Polymerase Chain Reaction) atau biakan darah untuk membantu menegakkan diagnosis, menetapkan prognosis, memantau perjalaanan penyakit serta hasil pengobatan (Kautsar, 2017).

Sefiksim merupakan antibiotik generasi ketiga sefalosporin, yang digunakan untuk mengobati infeksi yang disebabkan bakteri. Efek bakterisidal dengan menghambat sintesis dinding sel, dengan mengikat ke salah satu protein yang mengikat penisilin atau Penicillin Binding Proteins (PBPs) yang menghambat langkah trans peptidation akhir dari sintesis pepidoglikan di dinding sel bakteri sehingga menghambat biosintesis dan mengakibatkan kematian sel bakteri (Sitorus, 2015).

Telah banyak penelitian mencari obat alternatif dalam pengobatan demam tifoid diantaranya seftriakson dan siprofloksasin adalah yang paling banyak diuji coba (Rismarini et al., 2001). Seftriakson dianggap sebagai obat yang poten dan efektif untuk pengobatan demam tifoid dalam jangka pendek. Sifat yang menguntungkan dari obat ini adalah secara selektif dapat merusak struktur kuman dan tidak mengganggu sel tubuh manusia, mempunyai spektrum luas, resistensi kuman masih terbatas, tetapi harga obat tersebut cukup mahal.

Menurut (Haluang et al., 2015) rata-rata biaya penggunaan antibiotik pada penderita demam tifoid, sefiksim sebesar Rp122.729 dan seftriakson Rp136.136, total biaya ini juga dipengaruhi dengan lama rawat inap tiap pasien. Dari data yang diperoleh pada pasien demam tifoid anak dengan status pasien umum menunjukkan bahwa jenis antibiotik tiamfenikol, kloramfenikol dan siprofloksasin lebih cepat waktu penyembuhannya yaitu masing-masing memiliki rata-rata lama perawatan 4 hari. Penggunaan antibiotik dengan biaya yang relatif tinggi belum tentu bisa menjamin efektifitas perawatan pasien.

Analisis farmakoekonomi merupakan cara yang komprehensif untuk menentukan pengaruh ekonomi dari alternatif tarapi obat atau intervensi kesehatan lain. Pada intervensi farmasi, farmakoekonomi digunakan untuk menilai apakah tambahan keuntungan dari suatu intervensi sepadan dengan biaya tambahan dari intervensi tersebut (Andayani, 2013).

Pada umumnya pengobatan demam tifoid di RSU Anutapura Palu diberikan infus dekstrosa maupun cairan ringer laktat, diberikan parasetamol untuk menurunkan demam dan antibiotik yang diberikan pada umumnya golongan sefalosporin khususnya seftriakson. Tes laboratorium yang dilakukan tes uji widal maupun pemeriksaan darah rutin. Dari hasil survei peneliti pada 6 November 2017 dari bagian rekam medik Rumah Sakit Umum Anutapura Palu diperoleh data pada tahun 20152017 sebanyak 252 pasien tanpa komplikasi yang menjalani rawat inap. Berdasarkan latar belakang diatas, maka penulis tertarik melakukan penelitian ini dimana bertujuan untuk mengetahui gambaran penggunaan antibiotik serta biayanya pada pasien demam tifoid di RSU Anutapura Palu periode 2015-2017.

\section{Tujuan Penelitian}

1. Mengetahui direct medical costs penggunaan seftriakson dan sefiksim pada pasien demam tifoid rawat inap RSU Anutapura Palu periode 2015-2017.

2. Mengetahui antibiotik yang paling costeffective antara seftriakson dan sefiksim pada pasien demam tifoid rawat inap RSU Anutapura Palu periode 2015-2017 berdasarkan perhitungan ACER dan ICER?

\section{METODOLOGI PENELITIAN}

Desain Penelitian. Jenis penelitian yang akan digunakan dalam penelitian ini merupakan penelitian yang bersifat kuantitatif dengan pengambilan data dilakukan secara retrospektif, menggunakan data sekunder berupa rekam medik dan bukti pembayaran pengobatan serta membandingkan direct medical cost (biaya langsung medis) dari penggunaan antibiotik seftriakson dan sefiksim pada pasien demam tifoid yang menjalani rawat inap di RSU Anutapura Palu periode 2015-2017. Pengolahan data dihitung dengan menggunakan CEA (Cost Effectiveness Analysis) berdasarkan nilai ACER (Average CostEffectiveness Ratio) dan ICER (Incremental CostEffectiveness Ratio) untuk efektifitas biaya.

Tempat dan Waktu Penelitian. Lokasi penelitian ini dilakukan di RSU Anutapura Palu dan dilaksanakan pada bulan Februari - April 2018.

Populasi dan Sampel Penelitian. Populasi pada penelitian ini adalah semua pasien demam tifoid yang menjalani rawat inap di RSU Anutapura Palu Periode 2015-2017. Sampel penelitian, yaitu:

Kriteria Inklusi:

a. Pasien yang terdiagnosa demam tifoid tanpa penyakit penyerta di RSU Anutapura Palu Periode 2015-2017.

b. Pasien yang diberikan antibiotik tunggal.

c. Pasien demam tifoid yang dinyatakan sembuh dari demam tifoid oleh dokter. 
Kriteria Eksklusi:

a. Pasien dengan data rekam medis yang tidak lengkap, hilang, tidak jelas terbaca.

b. Pasien pulang paksa/meninggal.

c. Pasien yang mengalami pergantian antibiotik selama perawatan.

Pengumpulan dan Analisis Data. Pengumpulan data dilakukan dengan pencatatan rekam medik pasien meliputi nama, umur, jenis kelamin, pendidikan, pekerjaan, jenis obat yang digunakan, dan penurunan suhu tubuh dan hilangnya demam , serta biaya medis langsung pasien meliputi biaya antibiotik, biaya pemeriksaan laboratorium, biaya kamar inap, biaya tindakan medis dan biaya obat penunjang. Analisis data yang digunakan dalam penelitian ini adalah uji statistik deskriptif yang bertujuan untuk menjelaskan atau memberikan gambaran karakteristik setiap variabel penelitian melipuuti:

1. Karakteristik subyek penelitian
a. Jenis kelamin
b. Umur
c. Jenis antibiotik tunggal

2. Efektivitas pengobatan
a. Lama rawat inap
b. Penurunan suhu tubuh dan hari hilangnya demam

3. Perhitungan biaya
a. Biaya antibiotik
b. Biaya pemeriksaan laboratorium
c. Biaya kamar inap
d. Biaya oabt penunjang
e. Biaya tindakan medis
4. Perhitungan Cost Effectiveness Analysis (CEA). Efektivitas biaya dianalisis menggunakan rumus ACER (Average Cost- Effectiveness Ratio):

$$
\begin{gathered}
\mathrm{ACER}=\frac{\text { Biaya }}{\text { Efektivitas Terapi }} \\
\mathrm{ICER}=\frac{\Delta \text { Total Biaya }}{\Delta \text { Efektifitas }}
\end{gathered}
$$

\section{HASIL DAN PEMBAHASAN}

Tabel 1 Jumlah pasien demam tifoid di instalasi rawat inap RSU Anutapura 2015-2017.

\begin{tabular}{l|c}
\hline Pasien Demam Tifoid & Jumlah Pasien \\
\hline Memenuhi kriteria & 30 \\
Tidak memenuhi kriteria & 222 \\
\hline Total & 252 \\
\hline
\end{tabular}

Berdasarkan tabel 1 total pasien demam tifoid tanpa penyakit penyerta di instalasi rawat inap RSU Anutapura sebanyak 252 pasien, jumlah pasien yang memenuhi kriteria untuk dianalisis lebih lanjut berjumlah 30 pasien. Pasien yang tidak memenuhi kriteria berjumlah 222 pasien. Hal ini disebabkan karena data pasien yang tidak lengkap, tes laboratorium yang tidak lengkap dan penggunaan antibiotik selain seftriakson dan sefiksim.

Tabel 2 Distribusi jenis kelamin dan usia yang mengalami demam tifoid di instalasi rawat inap RSU Anutapura.

\begin{tabular}{lcc}
\hline \multicolumn{1}{c}{ Kategori } & $\begin{array}{c}\text { Jumlah } \\
(\mathbf{n = 3 0})\end{array}$ & $\begin{array}{c}\text { Persentase } \\
(\boldsymbol{\%})\end{array}$ \\
\hline Jenis Kelamin & & \\
\hline Laki -Laki & 16 & 53 \\
Perempuan & 14 & 47 \\
\hline Usia & & \\
\hline 4-14 tahun & 6 & 20 \\
15-44 tahun & 20 & 67 \\
45-59 tahun & 4 & 13 \\
\hline
\end{tabular}

Berdasarkan tabel 2 menunjukkan bahwa 16 pasien $(53 \%)$ demam tifoid berjenis kelamin lakilaki dan 14 pasien (47\%) berjenis kelamin perempuan. Hal ini sesuai dengan penelitian Sari (2017), dimana kasus demam tifoid pada pasien berjenis kelamin laki-laki lebih banyak dibandingkan dengan perempuan, dengan persentase $60 \%$ (24 pasien) dan pada perempuan 40\% (16 pasien). Hal ini disebabkan karena lakilaki banyak melakukan aktifitas di luar rumah sehingga memungkinkan mendapatkan risiko lebih besar dibandingkan perempuan (Musnelina, dkk, 2004). Namun tidak ada perbedaan yang nyata terhadap insidens tifoid antara pria dan wanita (Kepmenkes, 2006).

Kategori usia yang digunakan pada penelitian ini didasarkan pada penggolongan usia menurut Kemenkes RI (2011). Usia pasien demam tifoid rawat inap RSU Anutapura Palu periode 2015-2017 paling banyak diderita oleh kelompok usia 15-44 tahun sebanayak 20 pasien $(67 \%)$ disusul kelompok usia 4-11 tahun 6 pasien (20\%), dan 45-59 tahun sebanyak 4 pasien (13\%). Hal ini sejalan dengan penelitian Fithria, dkk (2014) dimana kasus demam tifoid dengan kelompok usia 15-44 tahun sebanyak 58 pasien $(81,7 \%)$ dibandingkan dengan kelompok usia 45-59 tahun sebanyak 7 pasien $(9,85 \%)$ ). Persentase tertinggi angka kejadian demam tifoid terjadi pada kategori usia 15-44 tahun (produktif). Demam tifoid sangat erat kaitannya dengan kualitas yang mendalam dari kebersihan pribadi dan sanitasi lingkungan, seperti kebersihan perorangan dan kebersihan penjamah makanan yang rendah, lingkungan yang kumuh, kebersihan tempat-tempat umum (rumah makan 
atau restoran) yang kurang serta perilaku masyarakat yang tidak mendukung untuk hidup sehat (Kepmenkes, 2006).

Tabel 3 Distribusi jenis antibiotik yang digunakan pasien demam tifoid yang menjalani rawat inap di RSU Anutapura.

\begin{tabular}{lcc}
\hline Antibiotik & Jumlah pasien & Persentase (\%) \\
\hline Seftriakson & 16 & 53 \\
Sefiksim & 14 & 47 \\
\hline Total & 30 & 100 \\
\hline
\end{tabular}

Untuk jenis antibiotik, diketahui pasien demam tifoid rawat inap RSU Anutapura yang menggunakan antibiotik seftriakson sebanyak 16 pasien $(53 \%)$ dan sefiksim sebanyak 14 pasien (47\%). Dari hasil penelitian dapat dilihat penggunaan seftriakson lebih banyak dibandingkan sefiksim. Hal ini disebabkan karena seftriakson merupakan antibiotik pilihan utama yang digunakan pada pasien demam tifoid rawat inap RSU Anutapura Palu. Seftriakson adalah antibiotik yang paling umum digunakan karena potensi antibakteri yang tinggi, spektrum yang luas dan potensi yang rendah untuk toksisitas. Alasan yang digunakan secara luas karena seftriakson merupakan golongan sefalosporin generasi ketiga yang merupakan antibiotik spektrum luas dapat mengatasi baik pada bakteri gram positif maupun gram negatif (Tjay dan Rahardja, 2013).

Tabel 4 Suhu tubuh rata-rata baseline hingga suhu tubuh pasien demam tifoid turun yang menggunakan seftriakson dan sefiksim yang menjalani rawat inap di RSU Anutapura.

\begin{tabular}{lcccccc}
\hline \multirow{2}{*}{ Antibiotik } & \multicolumn{2}{c}{$\begin{array}{c}\text { Baseline } \\
\left({ }^{\circ} \mathrm{C}\right)\end{array}$} & \multicolumn{2}{c}{$\begin{array}{c}\text { Suhu Turun } \\
\left({ }^{0} \mathrm{C}\right)\end{array}$} & \multicolumn{2}{c}{$\begin{array}{c}\text { Hari hilangnya } \\
\text { demam }\end{array}$} \\
\cline { 2 - 7 } & Mean & $\%$ & Mean & $\%$ & Mean & $\%$ \\
\hline Seftriakson & 38,16 & 50 & 36,3 & 50 & 3,68 & 49 \\
Sefiksim & 38,17 & 50 & 36,3 & 50 & 3,85 & 51 \\
\hline Total & & 100 & & 100 & & 100 \\
\hline
\end{tabular}

Tabel 4 menunjukkan rata-rata suhu tubuh dan hari hilangnya demam pasien demam tifoid yang menggunakan antibiotik seftriakson dan sefiksim di RSU Anutapura. Dimana baseline merupakan suhu tubuh awal pasien sebelum menjalani pengobatan hingga suhu tubuh menurun atau dengan kata lain suhu pasien kembali normal dan tidak meningkat. Pasien yang menggunakan terapi antibiotik seftriakson sebanyak 16 pasien menunjukkan rata-rata suhu awal masuk sebesar $38,16^{\circ} \mathrm{C}(50 \%)$ hingga suhu kembali normal dan tidak meningkat menjadi $36,3^{\circ} \mathrm{C}(50 \%)$ sedangkan yang menggunakan terapi antibiotik sefiksim sebesar $38,17^{\circ} \mathrm{C}(50 \%)$ hingga suhu kembali normal dan tidak meningkat sebesar $36,3^{\circ} \mathrm{C}(50 \%)$. Demam pada pasien demam tifoid yang menggunakan antibiotik seftriakson menunjukkan rata-rata pada hari ke 3,69 (3-4 hari) dan antibiotik sefiksim menunjukkan rata-rata hari ke 3,86 (3-4 hari).

Tabel 5 Rekapitulasi biaya medis langsung ratarata pasien demam tifoid rawat inap $\geq 7$ hari di RSU Anutapura.

\begin{tabular}{lcc}
\hline \multirow{2}{*}{ Komponen Biaya } & Seftriakson & Sefiksim \\
\cline { 2 - 3 } & $\begin{array}{c}\text { Mean } \\
(\mathbf{R p})\end{array}$ & $\begin{array}{c}\text { Mean } \\
(\mathbf{R p})\end{array}$ \\
\hline Biaya kamar Inap & 912.000 & 1.008 .000 \\
Biaya Laboratorium & 246.000 & 279.400 \\
Biaya Tindakan Medis & 225.700 & 280.800 \\
Biaya Antibiotik & 101.964 & 43.200 \\
Biaya obat Penunjang & 301.838 & 395.753 \\
Biaya Alat Kesehatan & 143.625 & 163.371 \\
\hline Total Biaya (Rp) & 1.931 .127 & 2.170 .524 \\
\hline
\end{tabular}

Tabel 6 Rekapitulasi biaya medis langsung ratarata pasien demam tifoid rawat inap $<7$ hari di RSU Anutapura.

\begin{tabular}{lcc}
\hline \multirow{2}{*}{ Komponen Biaya } & \multicolumn{2}{c}{ Seftriakson Sefiksim } \\
\cline { 2 - 3 } & $\begin{array}{c}\text { Mean } \\
(\mathbf{R p})\end{array}$ & $\begin{array}{c}\text { Mean } \\
(\mathbf{R p})\end{array}$ \\
\hline Biaya kamar Inap & 545.455 & 573.333 \\
Biaya Laboratorium & 231.545 & 178.111 \\
Biaya Tindakan Medis & 126.182 & 89.000 \\
Biaya Antibiotik & 89.510 & 22.445 \\
Biaya obat Penunjang & 251.745 & 253.783 \\
Biaya Alat Kesehatan & 99.189 & 88.683 \\
\hline Total Biaya (Rp) & 1.343 .626 & 1.205 .355 \\
\hline
\end{tabular}

Total biaya medis langsung merupakan total keseluruhan biaya yang dikeluarkan pasien mulai sejak pasien masuk rumah sakit hingga keluar dari rumah sakit dan dinyatakan sembuh. Biaya medis langsung meliputi biaya kamar inap, biaya laboratorium, biaya tindakan medis, biaya antibiotik, biaya obat penunjang, dan biaya alat kesehatan. Berdasarkan tabel 5 menunjukkan bahwa total biaya medis langsung pasien demam tifoid menggunakan antibiotik seftriakson yang menjalani rawat inap $\geq 7$ hari sebesar Rp1.931.127 dan yang menjalani rawat inap $<7$ hari sebesar Rp1.343.626 sedangkan yang yang menjalani rawat inap $\geq 7$ hari menggunakan antibiotik sefiksim sebesar Rp2.170.524 sedangkan yang menjalani rawat inap $<7$ hari sebesar Rp1.205.355.

Berdasarkan hasil yang diperoleh, terlihat bahwa total biaya medis langsung pasien demam tifoid yang menjalani rawat inap $\geq 7$ hari lebih mahal dibandingkan pasien yang menjalani rawat inap $<7$ hari, hal ini disebabkan karena semakin lama pasien menjalani rawat inap maka semakin mahal pula biaya medis langsungnya dan total biaya medik langsung penggunaan seftriakson $<7$ hari lebih mahal dibandingkan dengan sefiksim 
karena sediaan injeksi lebih mahal dibandingkan dengan sediaan kapsul.

\section{Analisis Efektifitas Biaya}

Tabel 7 Analisis Cost Effectiveness terhadap biaya penggunaan antibiotik per perawatan pasien demam tifoid rawat inap di RSU Anutapura.

\begin{tabular}{lccc}
\hline \multicolumn{1}{c}{$\begin{array}{c}\text { Biaya Medis } \\
\text { Antibiotik }\end{array}$} & $\begin{array}{c}\text { langsung per } \\
\text { perawatan } \\
(\mathrm{Rp})(\mathrm{C})\end{array}$ & $\begin{array}{c}\text { \% } \\
\text { Outcome } \\
(\mathrm{E})<7\end{array}$ & $\begin{array}{c}\text { ACER } \\
\text { hari }\end{array}$ \\
& $\begin{array}{c}\mathrm{C} / \mathrm{E}) \\
\end{array}$ & & \\
\hline Seftriakson & 1.931 .127 & 31,25 & $61.796,06$ \\
Sefiksim & 2.170 .524 & 35,71 & $60.781,97$ \\
\hline
\end{tabular}

Tabel 8 Analisis ICER terhadap terhadap biaya penggunaan antibiotik per perawatan pada pasien demam tifoid rawat inap di RSU Anutapura Palu.

\begin{tabular}{cccccc}
\hline Jenis & $\begin{array}{c}\text { Biaya Medis } \\
\text { Langsung per } \\
\text { perawatan } \\
(\mathrm{Rp})(\mathrm{C}) \\
\geq 7 \text { hari }\end{array}$ & $\begin{array}{c}\text { \% Total } \\
\text { Outcome } \\
(\mathrm{E})\end{array}$ & $\Delta \mathrm{C}$ & $\Delta \mathrm{E}$ & $\begin{array}{c}\text { ICER } \\
(\Delta \mathrm{C} / \Delta \mathrm{E})\end{array}$ \\
\hline $\begin{array}{c}\text { Seftriakson } \\
\text { (Standar) }\end{array}$ & $\begin{array}{c}1.931 .127 \\
\text { Sefiksim }\end{array}$ & 31,25 & & & \\
\hline Sefik & 2.170 .524 & 35,71 & & & \\
\hline
\end{tabular}

\section{Keterangan}

$\Delta \mathrm{C}$ :Jumlah selisih antara rata-rata biaya medis langsung penggunaan antobiotik seftriakson $\left(\mathrm{C}_{1}\right)$ dengan rata-rata biaya medis langsung penggunaan antibiotik sefiksim $\left(\mathrm{C}_{0}\right)$

$\Delta \mathrm{E}$ : Jumlah selisih anatara $\%$ efektifitas pengobatan demam tifoid \% outcome antibiotik seftriakson dengan $\%$ efektifitas pengobatan demam tifoid $\%$ outcome sefiksim.

Analisis efektifitas biaya (CEA) dilakukan menggunakan rumus Average Cost-Effectiveness Ratio (ACER) dan Incremental Cost-Effectiveness Ratio (ICER). Nilai ACER diperoleh dari perbandingan antara biaya total penggunaan obat rata-rata per perawatan dengan efektifitas atau outcome. Efektifitas atau outcome yang diukur adalah \% outcome klinis setelah menjalani perawatan. Pada tabel 6 menunjukkan bahwa nilai ACER dari antibiotik seftriakson dengan \% outcome klinis 31,25\% sebesar Rp. 61.796,06 dan nilai ACER antibiotik sefiksim dengan \% outcome klinis 35,71\% sebesar Rp. 60.781,87.

Dari hasil yang diperoleh, menunjukkan adanya perbedaan antara nilai ACER yang diperoleh pasien yang menggunakan antibiotik seftriakson dengan nilai ACER yang diperoleh pasien demam tifoid yang menggunakan antibiotik sefiksim. Nilai ACER pada pasien demam tifoid yang menggunakan antibiotik seftriakson lebih besar dibandingkan dengan pasien demam tifoid yang menggunakan antibiotik sefiksim. Semakin rendah nilai ACER, maka semakin cost effective karena dengan penggunaan biaya obat yang rendah mampu memberikan hasil penggunaan yang lebih tinggi. Meskipun ACER memberikan informasi yang bermanfaat, tetapi ICER merupakan ciri dari CEA, analisis incremental harus dilakukan dalam CEA. Nilai ICER diperoleh dengan perbandingan dari perbedaan biaya dibagi dengan perbedaan nilai outcome (Andayani, 2013). Pada tabel 8 nilai ICER yang diperoleh sebear $\mathrm{Rp}$ 53.676,45. Jika perhitungan ICER memberikan hasil negatif atau lebih kecil, maka suatu terapi lebih efektif dan lebih murah dibandingkan dengan alternatifnya. Nilai ACER yang diperoleh merupakan besarnya biaya tambahan yang diperlukan untuk memperoleh $1 \%$ outcome/kesembuhan. Jadi biaya yang dibutuhkan untuk mecapai $1 \%$ outcome kesembuhan sebesar Rp 53.676,45.

\section{DAFTAR PUSTAKA}

Andayani, T. M. (2013). Farmakoekonomi: Prinsip dan Metodologi. Yogyakarta: Bursa Ilmu

Fithria, R. F. dkk. (2015). Perbedaan Efektivitas Antibiotik Pada Terapi Demam Tifoid Di Puskesmas Bancak Kabupaten Semarang Tahun 2014. Prosiding Seminar Nasional Peluang Herbal Sebagai Alternatif Medicine, ISBN: 978-602-19556-2-8, 1-6

Haluang, O., dkk. (2015). Analisis Biaya Penggunaan Antibiotik Pada Penderita Demam Tifoid Anak Di Instalasi Rawat Inap RSUP Prof. Dr. R.D. Kandou Manado Periode Januari 2013 - Juni 2014. Pharmacon, 4(3), 117-125.

Kautsar, G. P. S. dan A. P. (2017). Perbandingan Metode Diagnosis Demam Tifoid. Perbandingan Metode Diagnosis Demam Tifoid, 4, 1-13

Keputusan Mentri Kesehatan, R. I. (2006). Pedoman Pengendalian Demam Tifoid (Kepmenkes RI No. 364/MENKES/SK/V/2006). Jakarta: Mentri Kesehatan Republik Indonesia.

Kementrian Kesehatan Republik Indonesia. (2011). Data Penduduk sasaran Program Pembangunan kesehatan 2011-2014. Jakarta: Pusat dan Informasi Kementrian Kesehatan republik Indonesia 
Musnelina, L., et al.. (2004). Analisis Efektivitas Biaya Pengobatan Demam Tifoid Anak Menggunakan Kloramfenikol Dan Seftriakson Di Rumah Sakit Fatmawati Jakarta Tahun 2001 - 2002. Mekara, Kesehatan 8(2). 59-64

Nelwan, R. (2012). Tata Laksana Terkini Demam Tifoid. Cdk, 39(4), 247-250

Rismarini, Anwar Z., \& Merdjani., A. (2001). Perbandingan Efektifitas Klinis antara Kloramfenikol dan Tiamfenikol dalam Pengobatan Demam Tifoid pada Anak. Sari Pediatri, 3(2), 83-87
Susono, F. R., dkk. (2014). Cost Effectiveness Analysis Pasien Demam Tifoid Pediatrik Menggunakan Cefotaxime danm Cloramphenicol Di Instalasi Rawat Inap RSUD Prof. Dr. Margono Soekarjo. Pharmacy, 11(1)

Sitorus, N. (2015). Efektivitas Obat Kombipak (Kombinasi Obat Sefiksim Dan Azitromisin) Terhadap Servisitis Gonore Dan Dugaan Servisitis Non Spesifik Pada Wanita Pekerja Seksual Di Wilayah Kerja Puskesmas Bandar Baru Kabupaten Deli Serdang. Medan: Universitas Sumatra Utara

Tjay, T. H. \& Rahardja, K. (2013). Obat-Obat Penting. Jakarta: PT. Elex Media Komputindo. 